\title{
PROSES MORFOLOGIS DALAM BAHASA DAYAK TUNJUNG DI KABUPATEN KUTAI BARAT, PROVINSI KALIMANTAN TIMUR
}

\author{
(Morphological Process in Dayak Tunjung Language in Kutai Barat Regency, \\ East Kalimantan Province) \\ Halimi Hadibrata \\ Kantor Bahasa Bengkulu \\ Jalan Kapuas 4 No. 9, RT. 16 / 05, Padang Harapan, Gading Cemp., \\ Kota Bengkulu, Bengkulu, Indonesia \\ Pos-el: brata_11268@yahoo.com
}

\begin{abstract}
Abstrak: Tujuan penelitian ini untuk menentukan kelas kata dan mendeskripsikan proses morfologis dalam bahasa Dayak Tunjung yang digunakan oleh masyarakat di Kabupaten Kutai Barat, Provinsi Kalimantan Timur. Penelitian ini merupakan penelitian deskriptif kualitatif dengan menggunakan metode survei dan rekam dalam pengumpulan data. Data dianalisis dengan pendekatan paradigma penurunan kata dan valensi. Pendekatan paradigma penurunan kata dilakukan dengan afiksasi, reduplikasi, dan pemajemukan untuk menemukan derivasi kelas kata nomina, adjektiva, verba, dan adverbia. Model valensi kata dalam struktur kalimat diterapkan untuk menemukan kelas kata preposisi dan konjungtor. Hasil analisis menunjukkan bahwa bahasa Dayak Tunjung memiliki kelas kata nomina, verba, adjektiva, adverbia, preposisi, dan konjungtor.
\end{abstract}

Kata Kunci: Dayak Tunjung, morfologi, kelas kata, paradigma, valensi

\begin{abstract}
The aim of this research is to discover word class and describing the morphological process of word-formation in Dayak Tunjung. This language is spoken by citizen of West Kutai Region, East Kalimantan. This research applies the qualitative method. The data is collected through survey and note-taking technique. The data is analyzed by using the word-paradigm and valency approach. The word-formation paradigm by affixation, reduplication, and composition to discover word derivation as noun, verb, adjective, and adverb. The valency model of word in sentence is applied to discover preposition and conjunction word class. The result shows that the given language has several word classes, namely noun, verb, adjective, adverb, preposition and conjunction.
\end{abstract}

Keywords: Dayak Tunjung, morphology, parts of speech, paradigm, valency

\section{PENDAHULUAN}

Setiap bahasa pada umumnya memiliki berbagai jenis kata yang dapat dikategorikan ke dalam kelas-kelas kata. Kelas kata nomina dan verba merupakan kelas kata utama yang relatif selalu ada dalam setiap bahasa. Bagaimana relasi antarkeduanya diwujudkan dalam struktur bahasa dan pemarkahannya, setiap bahasa memiliki keunikan tersendiri. Misalnya, bahasa Dayak Tunjung (BDT) yang memiliki perbedaan dengan bahasa Indonesia dalam pembentukan verba. Dari hasil pengamatan terhadap BDT dapat diketahui bahwa sebuah leksikon yang berkategori verba mengandung pula makna jenis pelaku (persona) dan kala (modalitas) kejadian perbuatan. Oleh karena itu, kajian kategori atau kelas kata yang diidentifikasi dari kalimat-kalimat yang bervariasi sangat penting untuk menambah khazanah ilmu bahasa di Indonesia.

BDT dituturkan oleh masyarakat di Kabupaten Kutai Barat dan Kutai Kartanegara, Provinsi Kalimantan Timur. Bahasa Tunjung terdiri atas empat dialek, yaitu (1) dialek Ngenyan Asa yang 
dituturkan di Desa Linggang Melapeh, Kecamatan Linggang Bigung, dan desa Ngenyan Asa, Kecamatan Barong Tongkok, Kabupaten Kutai Barat; (2) Dialek Melapeh Baru yang dituturkan di Melapeh Baru, Kecamatan Linggang Bigung, Kabupaten Kutai Barat; (3) dialek Tanah Kelakat yang dituturkan di Tanah Kelakat, Kecamatan Kembang Janggut, Kabupaten Kutai Kartanegara; dan (4) dialek Muara Asa yang dituturkan di Desa Muara Asa, Kecamatan Barong Tongkok, dan Desa Bigung Baru, Kecamatan Linggang Bigung, Kabupaten Kutai Barat. Persentase perbedaan antardialek tersebut berkisar 54-65\%. Bahasa Tunjung memiliki perbedaan sekitar $85-95 \%$ jika dibandingkan dengan bahasa-bahasa lain yang ada di Kalimantan Timur. Perbedaan dengan bahasa Dusun berkisar $85 \%$, dengan bahasa Pasir $87 \%$, dengan bahasa Bugis 93\%, dan dengan bahasa Bahau Diaq Lay 95\%. (Sugono, 2008: 68).

Salah satu penelitian tentang subdialek BDT pernah dilakukan oleh Hadibrata dan Winarti (2007). Hadibrata menyimpulkan bahwa penamaaan bahasa dan dialek yang tersebar di masyarakat penutur BDT tidak terlepas dari pengaruh sebutan dan pengakuan dari para penuturnya sendiri. Sebagai contoh, isolek yang dituturkan masyarakat di Desa Linggang Melapeh, Kecamatan Linggang Bigung, disebut sebagai bahasa Dayak Rentenuunk. Namun, hasil identifikasi SIL (2006) menunjukkan bahwa BDT memiliki empat dialek, yaitu dialek Tunjung (Tunjung Tengah), Tunjung Londong, Tunjung Linggang, dan Pahu (Sugono, 2008, hlm. 68). Dengan demikian, isolek Rentenuunk di Linggang Bigung adalah dialek dari BDT.

Hasil penelitian Hadibrata dan Winarti (2007) menunjukkan bahwa secara kontrastif BDT dialek Rentenuunk tersebut menunjukkan kesamaan pada pembentukan kata dengan prefiks nasal, tetapi dalam hal lain banyak sekali perbedaannya. Oleh karena itu, penataan morfem dan kata dalam satuan leksikal sangat menarik untuk dikaji dengan pendekatan kategorisasi kelas kata berdasarkan proses penurunan katanya.

Pada dasarnya masih banyak hal yang belum terkuak mengenai BDT, tetapi pada makalah ini hanya disajikan proses morfologis pembentukan kata nomina, verba, dan adjektiva dengan model paradigma, serta penentuan kelas kata preposisi dan konjungtor dengan model valensi. Dengan demikian, masalah yang dibahas dalam makalah ini adalah bagaimana kelas kata dalam BDT dan penentuannya dengan model paradigm pembentukan kata dan valensi.

Menurut Kridalaksana (1994) kelas kata menempati posisi penting sejak ilmu bahasa dikembangkan para ahli bahasa. Aristoteles (abad ke-4 SM) dalam karyanya Peri Hermenias menjadikan kelas kata sebagai pokok bahasan khusus mengenai bahasa. Bahkan, dalam karya-karya yang kemudian di Eropa, rintisan Plato dan Aristoteles mengenai kelas kata menjadi acuan dalam tradisi gramatika Eropa, seperti Roman (1653) dan karya van Ophuyisen (1915) yang tersebar hingga ke Indonesia. Akan tetapi, konsep kelas kata pada karya-karya rintisan Plato dan Aristoles tidak begitu jelas bagi para ahli bahasa modern. Barulah pada abad ke-1 M dalam Tekhné Gramatiké karya Dyonisius Thrax konsep kelas kata menjadi jelas dan ciri-cirinya dirumuskan secara eksplisit. Dalam perkembangannya sesudah zaman Dyonisius, kelas kata dalam tradisi gramatika Eropa diamati dan didefinisikan menurut Donatus $(350 \mathrm{M})$ dan Priscianus $(512-560 \mathrm{M})$ yang dijadikan sumber pengembangan kajian kelas kata pada zaman selanjutnya.

Menurut Donatus (dalam Kridalaksana, 1994) kelas kata dalam tata bahasa Eropa terdiri atas delapan jenis. Yang pertama ialah nomina, yaitu kelas kata yang ditandai untuk kasus, menunjukkan tubuh atau benda yang bersifat khusus atau umum. Kedua, pronomina, yaitu kelas kata yang dipakai 
sebagai pengganti nomina, mempunyai makna yang hampir sama dengan persona. Ketiga, verba, yaitu kelas kata dengan kala dan persona, tidak ditandai untuk kasus, menunjukkan perbuatan atau penderitaan sesuatu, atau bukan keduanya. Keempat, partisipium, adalah kelas kata yang sebagian berasal dari nomina dengan mengambil genus dan kasusnya, sebagian dari verba dengan mengambil kala dan diatesisnya, dan dari keduanya diambil numeralia dan figura (pemarkah tunggal atau jamak). Kelima, adverbia, adalah kelas kata yang ditambahkan ke verba untuk membantu dan melengkapi maknanya. Keenam, preposisi, adalah kelas kata yang ditempatkan di depan kelas kata lain yang mengubah, menyempurnakan, atau mengurangi maknanya. Ketujuh, konjungtor, adalah kelas kata yang menghubung-hubungkan dan mengatur makna. Kedelapan, interjeksi, adalah kelas kata yang menunjukkan emosi melalui kata yang tak berbentuk.

Pendapat itu menunjukkan bahwa verba merupakan kelas kata yang menunjukkan kesatuan perbuatan atau penderitaan dengan kala (waktu tindak) dan persona (aspek penindak). Kelas kata persona sendiri didefinisikan sebagai pengganti nomina atau kata benda. Akan tetapi, klasifikasi kelas kata seperti ini perlu disederhanakan. Berdasarkan klasifikasi kelas kata Donatus di atas, Priscianus (dalam Kridalaksana, 1994) menyederhanakannya menjadi enam kelas kata. Keenam kelas kata tersebut ialah nomina, yaitu kelas kata yang memberikan kualitas umum atau khusus pada setiap tubuh atau benda; ajektiva, yaitu kelas kata yang ditambahkan pada nomina yang menandai substansi agar menunjukkan kualitas atau kuantitasnya; verba, yaitu kelas kata dengan kala dan modus tanpa kasus yang menandai perbuatan atau penderita; adverbia, yaitu kelas kata yang tidak dapat dideklinasikan dan pengertiannya ditambahkan pada verba; preposisi, yaitu kelas kata yang tidak dapat dideklinasikan dan ditempatkan di depan kelas kata lain baik secara terpisah maupun bergabung; dan konjungtor, yaitu kelas kata yang tidak dapat dideklinasikan, menyambung dan menandai kelas kata lain, serta menunjukkan kekuatan atau urutan maknanya.

Berdasarkan pendapat terakhir di atas deskripsi kelas kata sebuah bahasa (termasuk BDT) dapat dihipotesiskan ke dalam enam jenis, yaitu nomina, adjektiva, verba, adverbia, preposisi, dan konjungtor.

Ch.A.van Ophuiysen dalam bukunya Tata Bahasa Melayu (1983) membagi jenis kata nomina, preposisi, pronomina (terdiri atas demonstratif, persona, posesif, interogatif, relatif, taktentu), artikel, adjektiva, numeralia, verba, adverbia, konjungtor, dan interjeksi. Menurut van Ophuiysen, batas antara satu kelas kata dan kelas kata lain dalam bahasa Melayu, seperti juga dalam bahasa Belanda, tidak terlalu jelas dan tegas. Kata ketakutan, misalnya, dapat dikategorikan sebagai adjektiva dan dapat juga dikategorikan sebagai nomina.

Alwi (2003) membagi kelas kata bahasa Indonesia ke dalam kategorikategori berikut. Pertama, verba, yaitu kelas kata yang dapat diidentifikasi dan dibedakan dengan kelas kata lain, terutama dengan adjektiva. Verba biasanya berfungsi sebagai predikat atau sebagai inti predikat dalam kalimat, mengandung makna inheren perbuatan (aksi), proses, atau keadaan. Verba yang bermakna keadaan tidak dapat diimbuhi prefiks ter- yang berarti paling. Verba umumnya tidak dapat digabungkan dengan kata bermakna kesangatan, seperti *agak belajar, *sangat pergi, dan *bekerja sekali, walaupun ada kata sangat berbahaya, agak mengecewakan, mengharapkan sekali. Kedua, adjektiva, yaitu kata yang memberi keterangan lebih khusus tentang sesuatu yang dinyatakan nomina dalam kalimat. Ketiga, adverbia, yaitu kata yang dalam tataran frasa menjelaskan verba, adjektiva, atau adverbia lain, sedangkan dalam tataran klausa mewatasi atau menjelaskan fungsi-fungsi 
sintaksis. Keempat, nomina, yaitu kata yang mengacu pada manusia, binatang, benda, konsep, atau pengertian. Kelima, pronomina, yaitu kata yang dipakai untuk mengacu kepada nomina lain. Keenam, numeralia, yaitu kata yang digunakan untuk menghitung banyaknya maujud (orang, binatang, atau barang) dan konsep. Ketujuh, kata tugas, yaitu kata yang hanya memiliki makna gramatikal dan tidak memiliki makna leksikal. Kata tugas terdiri atas preposisi atau kata depan, yaitu kata yang menandai berbagai hubungan makna antara konstituen di depan preposisi tersebut dengan konstituen di belakangnya; konjungtor atau kata sambung, yaitu kata yang bertugas menyambungkan dua satuan bahasa yang sederajat; dan interjeksi atau kata seru yang berfungsi untuk mengungkapkan rasa hati pembicara.

$$
\text { Penelitian ini membatasi }
$$

pembentukan kelas kata nomina, verba, adjektiva, adverbia, preposisi, dan konjungtor melalui proses morfologis paradigma dan valensi leksikal.

\section{METODE PENELITIAN}

Pengambilan data penelitian ini dilakukan di Kota Samarinda, Kalimantan Timur. Analisis data dilakukan dengan pendekatan proses morfologis pembentukan kata dan model paradigma dan valensi yang dikembangkan oleh Teeuw (1962) dalam makalahnya "Some Problem in the Study of Word-Classes in Bahasa Indonesia" Teeuw membeda-bedakan kelas kata dengan pendekatan peran paradigma. Dengan pendekatan peran paradigma, ia menentukan kelas kata adjektiva melalui pembentukan kata dengan cara menentukan makna kata berdasarkan pemarkah morfologisnya yang memungkinkan disubstitusi dengan bentuk lain yang memiliki pola pembentukan dan makna kelas kata yang sama seperti melalui proses polimorfemis berikut.

1) Reduplikasi 'pengulangan' (R) seperti tenang-tenang.
2) Prefiks ter- sebagai pemarkah superlatif, seperti terbesar.

3) Prefiks maha- sebagai pemarkah superlatif, seperti mahabesar.

4) Prefiks $s e$ - sebagai pembentuk adjektiva pembanding, seperti sebesar.

5) se-R-nya sebagai pembentuk adjektiva superlatif, seperti sebesar-besarnya.

6) ke-an yang terdiri atas tipe ke-an sebagai pembentuk tipe adjektiva, seperti kebesaran; tipe ke-an sebagai pembentuk adjektiva, seperti kedinginan; dan tipe ke-R-an sebagai pembentuk adjektiva, seperti keputihputihan.

7) -nya sebagai pemarkah nomina posesif, seperti senangnya.

8) ber- sebagai pembentuk tipe adjektiva, seperti berbesar hati.

9) ber-R-an sebagai pembentuk tipe adjektiva, seperti berbaik-baikan.

10) me-sebagai pembentuk tipe adjektiva, seperti mendalam dan menjauh.

11) me-kan sebagai pembentuk tipe adjektiva, seperti membesarkan.

12) $p e$ - sebagai pembentuk tipe adjektiva, seperti pemalas.

Berdasarkan pendekatan paradigma seperti di atas, sebuah kata dapat diidentifikasi melalui paradigma pembentukannya secara morfemis dan makna kata bentukannya.

Berdasarkan valensinya, sebuah kata dapat ditentukan posisi urutan kata yang mendahului atau yang mengikutinya. Kehadiran sebuah pola urutan yang sama dapat digunakan sebagai penentu kelas kata tertentu. Di dalam penentuan kelas kata adjektiva dalam bahasa Indonesia, Teeuw (1962) menggunakan peran valensi pengurutan kata dengan pola berikut.

1) nomina+adjektiva, seperti rumah besar.

2) Nomina+yang+adjektiva, seperti rumah yang besar.

3) yang +adjektiva, seperti yang besar.

4) dengan+adjektiva, seperti dengan manis. 
5) urutan yang menyatakan tingkatan perbandingan dalam pola amat+adjektiva seperti amat besar dan agak+adjektiva, seperti agak besar.

6) urutan yang menyatakan tingkat perbandingan superlatif dengan pola adjektiva+sekali, seperti besar sekali, dan pola adjektiva+benar, seperti tua benar.

7) urutan yang menyatakan hubungan langsung dengan bilangan, seperti tiga yang putih.

8) urutan yang menyatakan penentu (takrif) dalam pola nomina-adjektivademonstratif, seperti rumah besar ini.

9) urutan adjektiva yang didahului kata bantu cara (modal), seperti harus, dapat, dan boleh.

Berdasarkan pola valensi di atas, kelas kata adjektiva memiliki posisi tertentu di dalam struktur kalimat yang dikendalai oleh kata yang mendahului dan kata yang mengikutinya. Dengan demikian, penggunaan peran paradigma pembentukan kata seperti pola pembentukan kata dengan afiksasi dan reduplikasi serta penentuan posisi urutan kata dalam kalimat seperti di atas dapat dikembangkan model penentuan kelas kata lain, seperti nomina, verba, adverbia, dan preposisi seperti diuraikan berdasarkan data BDT di bawah ini.

\section{PEMBAHASAN}

Pembahasan tentang nomina dan verba lebih luas dari yang lainnya. Pembahasan keduanya dilihat dari segi relasi perwujudan, pemarkahan, dan proses pembentukannya dengan cara afiksasi, reduplikasi, dan pemajemukan.

\section{Proses Morfologis Nomina}

Pembahasan mengenai proses morfologis nomina BDT dibatasi pada kelas kata nomina persona atau kata ganti orang yang sangat erat kaitannya dengan penurunan kata verba yang unik dalam BDT.

\section{Pembentukan Nomina Persona}

Bentuk-bentuk persona dapat digunakan dalam frasa nominal yang bervalensi dengan verba yang maknanya berkaitan dengan perasaan, kemauan, atau keinginan yang bersifat manusiawi. Berdasarkan data penelitian, nomina persona yang membentuk frasa verbal secara paradigmatik ialah

(a) persona pertama tunggal [aku?] 'saya',

(b) persona kedua tunggal [ko?] 'kamu',

(c) persona ketiga tunggal [sa?] 'dia', dan

(d) persona ketiga jamak [ēra?] 'mereka'.

Keempat jenis pronomina tersebut dapat dilihat contoh pemakaiannya sebagai berikut.

(1) [aku? ēwah] 'saya mau' $\rightarrow$ [aku?] 'saya',

(2) $[\mathrm{ko}$ ? ēwah] 'kamu mau' $\rightarrow$ [ko?] 'kamu',

(3) [sa? ēwah] 'dia mau' $\rightarrow$ [sa?] 'dia',

(4) [ēra? ēwah] 'mereka mau' $\rightarrow$ [ēra?] 'mereka'.

Keempat jenis persona ini dapat menduduki fungsi subjek dalam kalimat. Ketika berdistribusi dengan hal yang berhubungan dengan kepemilikan, pelaku perbuatan, dan yang dikenai perbuatan persona-persona tersebut direalisasikan dalam bentuk yang berbeda-beda.

Realisasi persona dalam empat hal tersebut dapat dilihat dalam bentuk-bentuk polimorfemis seperti diuraikan di bawah ini.

\section{Pembentukan Persona Posesif}

Persona posesif atau pemilik dalam BDT dapat dilihat keberadaan dan pemarkahannya seperti dalam nomina posesif di bawah ini.

a) [saga?] 'istri'

[saga:n] 'istriku' $\rightarrow\{-$ ang $\}=\{-\mathrm{ku}\}$

[saga:mp] 'istrimu' $\rightarrow\{-\mathrm{mp}\}=\{-\mathrm{mu}\}$

[saga:y] 'istrinya' $\rightarrow\{-a i\}=\{-n y a\}$

Kata sagak 'istri' yang mendapat pemarkah posesif dilafalkan dengan suku akhir [a:] sebelum $\{-n k\}$ atau $\{-$ 
ng\}, $\{-m p]$, atau $\{-$ ai $\}$ yang menjadi pemarkah persona posesif $\{-\mathrm{ku}\},\{-\mathrm{mu}\}$, atau $\{$-nya $\}$. Contoh ini menunjukkan perubahan sebagai berikut.

1. Persona pertama tunggal [aku?] 'aku' $\rightarrow\{$-ang $\}=\{-\mathrm{ku}\} \rightarrow$ posesifpertama tunggal.

2. Persona kedua tunggal [ko?] 'kamu' $\rightarrow\{-\mathrm{mp}\}=\{-\mathrm{mu}\} \rightarrow$ posesif kedua tunggal.

3. Persona ketiga tunggal [sa?] 'dia' $\rightarrow\{-$ $\mathrm{i}\}=\{-$ nya $\} \rightarrow$ posesif ketiga tunggal.

b) [ $\left.{ }^{\mathrm{n}} \mathrm{cu}: \mathrm{nk}\right]^{\text {'cucuku' }} \rightarrow\{-\mathrm{ng}\}=\{-\mathrm{ku}\}$; [ $\left.{ }^{\mathrm{n}} \mathrm{cu}: \mathrm{mp}\right]$ 'cucumu' $\rightarrow\{-\mathrm{mp}\}=\{-\mathrm{mu}\}$; [ ${ }^{\mathrm{n}}$ cu:y]'cucunya' $\rightarrow\{-\mathrm{i}\}=\{-\mathrm{nya}\} ;$ ["cu:nkaē]'cucu dia' $\rightarrow\{-n k a \bar{e}\}=\{$ dia $\}$; [ $\left.{ }^{\mathrm{n}} \mathrm{cu}: \mathrm{n}\right]$ 'cucunya' $\rightarrow\{-$ un $\}=\{-$ nya $\}$.

c) [ga]'milik' $\rightarrow$ [gaē] 'miliknya' $\rightarrow\{-\bar{e}\}$ $=\{$-nya $\} \rightarrow$ tunggal;

[gēn ēra?]'milik mereka' $\rightarrow\{$ ēra? $\}$ 'mereka' $\rightarrow$ jamak.

Data morfologis (b) dan (c) di atas menunjukkan ada tiga jenis pemarkah yang merealisasikan makna pemilik orang ketiga tunggal, yaitu $\{-\mathrm{i}\},\{n k a \bar{e}\}$, $\{-\mathrm{n}\}$, dan $\{-\overline{\mathrm{e}}\}$. Untuk pemilik orang ketiga jamak dimarkahi dengan \{-èra?\}.

d) [laku:?] 'perbuatan' $\rightarrow\{-u$ ? $\}$ pemarkah kata dasar;

[laku:n] 'kelakuan' $\rightarrow\{$-uun $\}=$ bentuk dasar;

[laku:n] 'kelakuanku' $\rightarrow\{-\mathrm{ng}\}=\{-\mathrm{ku}\}$; [laku:mp] 'kelakuanmu' $\rightarrow\{-\mathrm{mp}\}=\{-$ $\mathrm{mu}$;

[lakuuy] 'kelakuannya' $\rightarrow \quad\{-\mathrm{i}\}=\{-$ nya ;

e) [inga?] 'teman' $\rightarrow\{-a$ ? $\}=$ ciri kata dasar yang netral atau pemarkah tanpa pemilik [ingam] 'temanmu' $\rightarrow\{-\mathrm{m}\}=\{-\mathrm{mu}\} \rightarrow$ pemilik orang kedua tunggal;

[inga:y]'temannya $\rightarrow\{-i\}=\{-$ nya $\} \rightarrow$ pemilik orang ketiga tunggal.

f) [wana:n] $\rightarrow$ 'suami' $\rightarrow\{-a ? /-$ an $\}=$ pemarkah kata dasar yang netral tanpa pemilik.

[wana:y] 'suamiku' $\rightarrow\{-n g\}=\{-$ $\mathrm{ku}\} \rightarrow$ pemilik orang pertama tunggal; [wana:m] 'suamimu' $\rightarrow\{-\mathrm{m}\}=\{-\mathrm{mu}\} \rightarrow$ pemilik orang kedua tunggal;

[wana: ${ }^{\left.y_{i}\right]}$ 'suaminya' $\rightarrow\{-\mathrm{i}\}=\{-$ nya $\} \rightarrow$ pemilik orang ketiga tunggal.

Berdasarkan bentuk-bentuk polimorfemis di atas bentuk persona milik atau posesif dalam bahasa Tunjung, yaitu

(1) pemilik pertama tunggal [aku?] 'aku' $\rightarrow\{-\mathrm{ng}\}=\{-\mathrm{ku}\}$;

(2) pemilik kedua tunggal [ko?] 'kamu' $\rightarrow\{-\mathrm{m}\} /\{-\mathrm{m}\}=\{-\mathrm{mu}\}$

(3) pemilik ketiga tunggal [sa?] 'dia' $\rightarrow$ $\{-n\} /\{-n k a \bar{e}\}$

(4) pemilik ketiga tunggal [sa?] 'dia' $\rightarrow$ $\{-\mathrm{i}\} /\{-\overline{\mathrm{e}}\}=\{-$ nya $\}$

(5) pemilik ketiga jamak tunggal [ēra?] 'mereka' $\rightarrow$ \{ēn ēra?\}.

Kelima jenis persona posesif tersebut dapat dikontraskan dengan kata dasar yang dimarkahi dengan $\{-a$ ? $\}$ sebagai pemarkah netral, tidak berposesif.

\section{Pembentukan Persona Pelaku Verba}

Nomina pelaku atau agen dengan perbuatan yang dilakukannya dalam BDT dapat dilihat dalam verba polimorfemis aktif dan pasif. Verba polimorfemis yang mengandung pemarkah nomina pelaku verba aktif muncul berbeda dengan verba dasar dan verba turunan yang netral. Verba dasar dalam BDT secara inhern telah mengandung makna perbuatan dan memiliki potensi untuk diturunkan menjadi bentuk lain yang memiliki makna komponensial lebih luas dengan kategori dan fungsi yang lebih jelas. Sebagai perbandingan, di dalam bahasa Indonesia, sebuah morfem polimorfemis yang memiliki makna dasar perbuatan tidak menunjukkan pelaku perbuatan aktif dan pasifnya, sedangkan di dalam BDT pemarkah netral, aktif, dan pasifnya ditunjukkan secara morfemis seperti contoh-contoh berikut. [aco]'beri' $\rightarrow$ [naco]'memberi' [aco:y] 'kuberi' $\rightarrow\{-n g\}=\{-k u\}$ (enklitik) [aco:i] 'dia memberi' $\rightarrow\{-\mathrm{i}\}=$ dia (enklitik) 
Bentuk-bentuk penurunan verba aktif di atas menunjukkan adanya relasi yang sangat dekat antara verba dan pelaku verba atau agentif, seperti [aco:y]'saya memberi' bukan *[aku? aco?] dan [aco:i] 'dia memberi' bukan *[sa? aco].
Berdasarkan uraian di atas dapat diketahui bahwa proses morfologis penurunan dan penentuan kelas kata pronomina seperti tabel di bawah ini.

Tabel 1 Proses Morfologis Penurunan dan Penentuan Kelas Kata

\begin{tabular}{|c|c|c|c|c|}
\hline \multicolumn{3}{|c|}{ Pronomina } & \multirow{2}{*}{$\begin{array}{l}\text { Posesif } \\
\qquad\{\text {-ang }\}=\{-\mathrm{ku}\}\end{array}$} & \multirow{2}{*}{$\begin{array}{c}\text { Pelaku verba akti } \\
\text { enklitik } \\
\text {-ang }=\{-\mathrm{ku}\}\end{array}$} \\
\hline 1 & tunggal & $\begin{array}{l}\text { aku? } \\
\text { 'saya', }\end{array}$ & & \\
\hline 2 & tunggal & $\begin{array}{l}\text { ko? } \\
\text { 'kamu' }\end{array}$ & $\{-m\}=(-m u)$ & $-m p=\{-k a u\}$ \\
\hline \multirow{3}{*}{3} & \multirow[t]{2}{*}{ tunggal } & \multirow[t]{2}{*}{ sa? 'dia' } & $\begin{array}{l}\{\mathrm{i}\} /\{\overline{\mathrm{e}}\} / \\
(\mathrm{dia} /\{-\mathrm{nya}\})\end{array}$ & $\begin{array}{l}\{-\mathrm{i}\} \\
\text { 'dia' }\end{array}$ \\
\hline & & & $\begin{array}{l}\{-n\} /\{-n k a \bar{e}\} \\
(\mathrm{dia} /\{- \text { nya }\})\end{array}$ & \\
\hline & jamak & & $\begin{array}{l}\{\text {-ēra? }\} \\
\text { 'mereka' }\end{array}$ & \\
\hline
\end{tabular}

\section{Pembentukan Adjektiva}

Adjektiva di dalam BDT berbeda sekali dengan adjektiva bahasa Indonesia, terutama dalam fungsinya yang bermakna perbandingan. Di dalam bahasa Indonesia dikenal tingkatan keadaan dingin, lebih dingin, dan sangat dingin atau dingin sekali. Perbandingan untuk kata dingin dapat digunakan kata panas, menjadi panas, lebih panas, dan panas sekali. Bentuk perbandingan seperti itu tampaknya tidak berlaku di dalam BDT. Sepintas, diketahui bahwa satu kata adjektiva memiliki tingkat superlatif tersendiri, seperti terlihat dalam contoh-contoh di bawah ini.
a) celap 'dingin', celap jelemït 'dingin sekali',
b) bulat 'bulat', bulat beletui 'bulat utuh', bebuling 'sangat bulat',
c) pejaai 'jelek', pejaai-pejeh 'jelek sekali'
d) pulaau 'pening', pulaau samun' pening sekali',

e) punaas 'habis', punaas nanas 'habis sama sekali',

f) pore 'bagus', pore-porus 'lumayan bagus',

g) pusęk 'penuh', pusęk dedęk 'penuh sesak atau penuh sekali',

h) pusing 'sibuk', pusing pening 'sibuk sekali atau kalang kabut'.

Berdasarkan contoh-contoh bentuk adjektiva di atas, pemarkah makna 'lebih' diwakili oleh porus 'lumayan'. Akan tetapi, penggunaannya hanya ditemukan pada pasangan dengan pore dalam pore porus tersebut sehingga masih diragukan untuk dapat digunakan dalam adjektiva lain. Bandingkan dengan pembentukan adjektiva perbandingan dalam bahasa Indonesia, misalnya baik, lebih baik, dan paling baik/terbaik. Bentuk superlatif seperti pejaai-pejeh 'jelek sekali', bebuling 'sangat bulat' dan celap jelemït 'dingin sekali' menunjukkan bahwa setiap adjektiva memiliki bentuk superlatif tersendiri. 


\section{Adjektiva dengan Reduplikasi}

Reduplikasi atau pengulangan dalam BDT merupakan cara pembentukan kata yang menghasilkan makna yang berbeda dengan bentuk dasarnya. Perbedaan makna tersebut disebabkan oleh pengulangan penuh bentuk dasar atau pengulangan sebagian dengan perubahan unsur-unsur fonem bentuk dasarnya. Berikut ini disajikan klasifikasi bentuk pengulangan dalam BDT menurut bentuk dan maknanya. Makna dan bentuk dasar kata ulang merupakan dasar identifikasi perubahan makna dasar itu, apakah terjadi pengulangan penuh atau pengulangan dengan perubahan unsur-unsurnya.

\section{Reduplikasi Dwilingga Adjektiva}

Pengulangan dengan cara dwilingga, yaitu pengulangan dengan mengulang seluruh bentuk dasar, baik pengulangan seluruh unsur bentuk dasar (dwimurni), pengulangan dengan perubahan sebagian unsur fonem bentuk dasarnya (dwireka), maupun pengulangan awal suku kata (dwipurwa).

\section{a) Adjektiva Dwimurni}

Contoh bentuk adjektiva dwimurni ialah gimir 'mudah terlepas, gimir-gimir 'hampir-hampir terlepas', tuhiq 'anak muda', tuhiq-tuhiq 'anak-anak muda', mangur 'tumbuhan muda', mangurmangur 'bunga-bunga muda', toq 'dekat', totoq 'dekat-dekat'. Adjektiva dwimurni yang bermakna 'muda' untuk kualitas sifat muda yang insani, yaitu tuhiq-tuhiq, dibedakan kualitas sifat muda untuk noninsani (tumbuhan), yaitu mangur-mangur.

b) Adjektiva dengan Dwireka

Bentuk-bentuk pengulangan dwireka yang membentuk adjektiva contohnya bonok 'gemuk', bonok-bontuq 'tetap gemuk', riak-riau 'berkilau-kilauan', dan rimēk-riku hingar-bingar'. c) Reduplikasi Dwipurwa Adjektiva

Bentuk-bentuk pengulangan ini merupakan reduplikasi dwipurwa, yaitu pengulangan sebagian suku awal bentuk dasarnya, yaitu gegayoong 'berayunayun', gegemut 'bergerak-gerak dengan tersembunyi di balik kain atau kulit', dan dengkös 'gaya berjalan', serta dedengkös 'berjalan dengan cepat'.

Di dalam bahasa Indonesia terdapat kata tetangga, sesama, sesaji, dan sesumbar. Keempat reduplikasi dwipurwa tersebut memiliki bentuk dasar masing-masing, yaitu tangga, sama, saji, dan sumbar.

\section{d) Adjektiva dengan Pemajemukan}

Adjektiva dapat dibentuk dengan pemajemukan, seperti gagah 'kuat', gagah gerahatn 'sehat walafiat', buncar 'rumput', dan buncar baih 'berserakan'.

\section{Pembentukan Verba}

\section{Pemarkah Verba, Persona, dan Kala}

Relasi verba dan kala dalam BDT dapat dilihat dalam perwujudan satuan leksikon. Satuan leksikon jenis ini memiliki bentuk netral yang tidak terikat waktu dan persona dengan pemarkah morfem $\{-\mathrm{a}: \mathrm{n}\}$ seperti beberapa contoh di bawah ini.

[èma?] 'pergi' $\rightarrow\{$-a? $\}$ netral.

[èma:n]'telah pergi/sepeninggal' $\rightarrow\{-$ a:n \} waktu lampau netral, tanpa pelaku.

[èma:y] 'setelah saya pergi' $\rightarrow\{-a: n g\}$

lampau.

[èma:i] 'setelah dia pergi' $\rightarrow \quad\{$-a:i $\}$

lampau.

[ėma:mp] 'setelah kamu pergi $\rightarrow\{-a: m p\}$ kala lampau.

Berdasarkan contoh di atas, verba pergi tak berkala dimarkahi dengan $\{-a ?\}$ dan kala lampau dimarkahi oleh bunyi panjang \{aa\}. Relasi morfemis seperti itu tidak ada di dalam bahasa Indonesia karena penataan konsep relasi waktu, persona, dan verba dalam bahasa Indonesia melalui penataan satuan leksikal berurut. 


\section{Pembentukan Verba Aktif}

Pembentukan verba dalam BDT dapat ditelusuri dengan menggunakan analisis penurunan leksikon dasar (D) dengan melihat peranan afiks. Afiks yang paling produktif di dalam BDT adalah afiks dengan nasal. Dengan menelusuri bentukbentuk nasal dapat ditemukan realisasi varian morfem nasal dalam bentuk $/ \mathrm{n} /, / \mathrm{m} /$, /ng/, atau /ny/ bergantung kepada fonem awal bentuk dasarnya, seperti dalam contoh berikut.

1) [akiq] 'minta' $\rightarrow$ [nakiq] 'meminta' $\rightarrow$ awal kata dasar /a/ $\rightarrow / \mathrm{n} /$.

2) [ala:u] 'pagar' $\rightarrow$ [yala:u] 'memagari' $\rightarrow$ awal kata dasar /a / $\rightarrow / \mathrm{ng} /$.

3) [atoky] 'palu' $\rightarrow$ [matoky] 'mematok dengan palu'

$\rightarrow$ awal kata dasar $/ \mathrm{a} / \rightarrow / \mathrm{m} /$

4) [pina:q]'tepat' $\rightarrow$ [minak] 'menepatkan arah' $\rightarrow$ awal kata dasar $/ \mathrm{p} / \rightarrow / \mathrm{m} /$.

[piko]'pakis' $\rightarrow$ [miko]'memakis (memetik pakis) $\rightarrow$ awal kata dasar $/ \mathrm{p} / \rightarrow / \mathrm{m} /$.

[pija] 'ikan peda' $\rightarrow$ [mija] 'memeda (membuat peda asin) $\rightarrow$ awal kata dasar $/ \mathrm{p} / \rightarrow / \mathrm{m} /$.

5) $\{$-ny $\} \rightarrow$ sebit 'bilah' $\rightarrow$ nyebit 'membelah' $\rightarrow$ awal kata dasar /s/ $\rightarrow$ /ny/

[sone] 'sandar' $\rightarrow$ nyone

'menyandarkan'

awal kata dasar /s/ $\rightarrow$ /ny/

[cehak] 'garam' $\rightarrow$ [ñehaq]

'menggarami' $\rightarrow$ awal kata dasar /s/

$\rightarrow$ /ny/.

Verba aktif BDT dibentuk dengan mengubah bentuk dasar dengan pengimbuhan afiksasi nasal. Data di atas menunjukkan bahwa penurunan verba aktif dapat dilakukan dengan mengimbuhkan fonem nasal $/ \mathrm{n} /$, /ng/, atau $/ \mathrm{m} /$ di depan bentuk dasar verba atau nomina yang diawali dengan vokal. Cara kedua, mengubah konsonan awal kata dasar nomina atau verba dengan fonem nasal $/ \mathrm{m} /$ untuk kata yang diawali dengan fonem $/ \mathrm{p} /$ dan morfem nasal /ny/ untuk kata yang diawali dengan fonem /s/.
Beberapa afiks pembentuk verba aktif dalam BDT seperti diuraikan di bawah ini. a. Verba Aktif dengan Prefiks Nasal Verba aktif dapat dibentuk dari bentuk dasar dengan prefiks nasal $(\mathrm{N})$ melalui proses morfofonemik seperti diuraikan di bawah ini.

1) Penurunan verba aktif dengan nasalisasi /ng/ yang meluluhkan fonem $/ \mathrm{k} /$ atau $/ \mathrm{g} / \mathrm{di}$ awal bentuk dasar dapat dirumuskan dengan /k/ atau /g/ $\rightarrow / \mathrm{ng} /$ seperti dalam contoh di bawah ini.

(1) [gampët] 'berdempet' $\rightarrow$ [ngampët] 'mendempetkan'.

(2) [kahing] 'pembayaran' $\rightarrow$ [ngahing] 'membayar'.

(3) [kalo:y]'tulisan' $\rightarrow$ [ngalokng] 'menuliskan'.

(4) [kana:y'kandang' $\rightarrow$ [yana:n] 'mengandangkan'.

(5) [kancin] 'kunci pintu' $\rightarrow$ [yancin]'mengunci pintu'.

(6) [kante:mp] 'rapat' $\rightarrow$ [yante:mp] 'menutup rapat'.

(7) $[$ karamp $]$ 'karam' $\rightarrow$ [yarapm] 'mengaramkan'

(8) [kotak] 'kotak' $\rightarrow$ [ngotak] 'membuat kotak'.

(9) [kuran]'kurang' $\rightarrow$ [yuran] 'mengurangkan'.

(10) [kurung] 'kurung' $\rightarrow$ [yuruy] 'mengurung'.

Contoh di atas menunjukkan bahwa dalam BDT fonem /g/ dan /k/ luluh oleh bunyi nasal. Hal ini berbeda dengan bahasa Indonesia. Fonem /g/ di awal kata dalam bahasa Indonesia tidak luluh oleh nasal /ng/, misalnya menggurui, menggunakan, menggugurkan, menggoda, dan menggantungkan.

2) Pembentukan verba aktif dengan asimilasi fonem /t/ di awal bentuk dasar dengan nasal /n/ seperti di bawah ini.

(1) [takar] 'takar' $\rightarrow$ [nakar] 'menakar.

(2) [tama:q]'masuk' $\rightarrow$ [nama:q] 'memasukkan'.

(3) [tantaai] 'penangkap ikan' $\rightarrow$ [nanta:i] 'menangkap ikan dengan tantai'. 
(4) [tekulu]'telungkup' $\rightarrow$ [nenkulu]

'menelungkupkan'.

(5) [tempo:r] 'tiang rumah' $\rightarrow$ [nempör] 'memasang tiang rumah'.

(6) [tempoy]'rebah $\rightarrow$ [nempoy] 'merebahkan'.

(7) [tẹkolo:u]'tumpah' $\rightarrow$ [nejkolöu] 'menumpahkan'

(8) [teretek]'cincang' $\rightarrow$ [neretek] 'mencincang'.

(9) [tika:y] 'lidi' $\rightarrow$ nikan 'melepas daun dari lidinya'.

(10) [timay]'timbang' $\rightarrow$ [nimay] 'menimbang'

Di dalam BDT bentuk dasar yang terdiri atas satu suku kata dapat diturunkan menjadi verba aktif dengan prefiks $\{$ me- $\}$ tanpa meluluhkan fonem awal suku kata dasarnya, seperti [tih] 'ini' $\rightarrow$ [metih] 'ke sini'.

3) Verba aktif dengan peluluhan fonem /s/ dan /c/ di awal bentuk dasar menjadi /ny/ dengan pola $/ \mathrm{s} / \rightarrow /$ ny/ atau $/ \mathrm{c} / \rightarrow /$ ny $/$ ), seperti [sebit] 'bilah kecil' $\rightarrow$ [ñyebit] 'membilah menjadi kecil', [sone] 'sandar' $\rightarrow$ [ñone] 'menyandarkan, dan [cehak] 'garam' $\rightarrow$ [ñehak] 'menggarami'.

4) Verba aktif dapat dibentuk dengan meluluhkan fonem konsonan /p/ dengan prefiks nasal $/ \mathrm{m} /$, seperti [piko] 'pakis' $\rightarrow$ [miko] 'memetik pakis', [pitap] 'kedipan mata' $\rightarrow$ [mitap] 'mengedipkan mata', [pukat] 'jala' $\rightarrow$ [mukat] 'menjala', [putik] 'dipungut' $\rightarrow$ [mutik] 'memungut'.

5) Verba aktif dapat dibentuk dengan prefiks $\{$ nge- $\}$ tanpa meluluhkan fonem konsonan /1/ pada awal suku kata dasar, seperti [loha:k]'dahak' $\rightarrow$ [yeloha:k] 'mendahak'.

6) Verba aktif dapat dibentuk dengan mengimbuhkan prefiks nasal $\{n\},\{m\}$ dan \{ng \} diawal bentuk dasar berfonem vokal tanpa meluluhkan fonem vokal pada awal bentuk dasar tersebut berupa deverbal dan denominal, seperti [aco?] 'beri' $\rightarrow$ [naco] 'memberi' (deverbal), [erè:k] 'irama musik tradisional' $\rightarrow$ [nėrè:k] 'membunyikan alat musik'(denominal), [atoon] 'palu' $\rightarrow$ [matoon] 'memalu' (denominal), [aseek] 'pasak' $\rightarrow$ [maseek]'memasang pasak' (denominal), [èsok] 'geser' $\rightarrow$ [yesok] 'menggeser' (deverbal), [ukir] 'ukir' $\rightarrow$ [yukir] 'mengukir' (deverbal), [agit] 'besi pengait' $\rightarrow$ [yagit] 'mengait' (denominal).

b. Verba Aktif dengan Prefiks \{per-\}

Pembentukan verba aktif dapat dilakukan dengan prefiks \{per-\} yang digunakan untuk menurunkan verba aktif dari bentuk dasar yang diawali dengan fonem /i/, seperti [incaamp] 'pinjam' $\rightarrow$ 'perincaamp' 'meminjamkan'.

c. Verba Aktif dengan Prefiks $\{b e-\}$

Prefiks $\{$ be- $\}$ dapat digunakan untuk membentuk verba aktif dari bentuk dasar yang diawali dengan fonem /s/ dan /g/ tanpa meluluhkan fonem awal suku katanya, seperti [soné] 'sandar' $\rightarrow$ [besone] 'bersandar', [gantar] 'gantar' $\rightarrow$ [begantar] 'menari gantar', dan [gahak] 'bicara' $\rightarrow$ [begahak] 'berbicara'.

d. Verba Aktif dengan Prefiks \{se-\}

Prefiks \{se- $\}$ digunakan secara terbatas untuk membentuk verba aktif denominal, seperti [jauy] 'jenis sayuran hutan seperti jagung' $\rightarrow$ [sejaung]'mencari jaung'.

e. Verba Aktif dengan Prefiks $\{$ me- $\}$

Prefiks $\{$ me- $\}$ digunakan untuk menurukan bentuk dasar menjadi verba aktif tanpa meluluhkan fonem awalnya, seperti [riwih] 'pancing' $\rightarrow$ [meriwih] 'memancing'. Proses morfologis ini menunjukkan perubahan kata dari bentuk dasar nomina riwih 'pancing' menjadi verba aktif meriwih.

\section{Pembentukan Verba Pasif}

Relasi verba dengan pronomina dalam BDT dapat dilihat juga dari segi objek yang dikenai perbuatan pelaku sehingga sebuah leksikon menunjukkan verba pasif seperti di bawah ini.

a. Pembentukan Verba Pasif dengan Prosodi Bunyi Vokal Panjang

Verba pasif dalam BDT dibentuk dengan verba dasar + aktif/pasif + pelaku, seperti [aco?] 'beri' $\rightarrow$ [naco] 'memberi' $\rightarrow$ nasal+dasar+Ø (tanpa nada panjang) dan 
[aco:nk] 'diberi oleh' $\rightarrow$ nasal+dasar $+\{-$ o:nk\} (dengan nada panjang).

Contoh ini menunjukkan bahwa nada pendek dengan vokal tertutup pada akhir kata kerja seperti $\{-\mathrm{o}$ ? $\}$ merupakan pemarkah kata kerja aktif, sedangkan nada panjang pada akhir kata kerja seperti \{o:nk\} merupakan pemarkah kata kerja pasif.

(1) [no?] 'mengambil'

[noonk]'diambil oleh saya'

$\rightarrow$ (nasal+dasar $+\{-0 o\}+\{-n k\})$

[noomp]'diambil olehmu' $\rightarrow$ nasal $+\{-$ oo- $\}+\{-\mathrm{mp}\}$

[nooi] 'diambil oleh dia' $\rightarrow$ nasal $+\{-0 o-$ \}$+\{-\mathrm{oy}\}$

[noon kaē] 'diambil olehnya' $\rightarrow$ nasal $+\{-0 o-\}+n+k a \bar{e}$

Data bahasa ini menunjukkan bahwa kata dasar nok dapat menurunkan kata turunan noong, noom, nooi, dan noon kaē. Nada panjang pada vokal akhir sebagai pemarkah verba pasif, sedangkan morfem di akhir kata $\{-n g\}, \quad\{-m p\}, \quad\{-i\} \quad$ dan $\{-k a \bar{e}\}$ merupakan pemarkah pelaku atau klitika akhir $\{-\mathrm{ku}\},\{-\mathrm{mu}\},\{-\mathrm{nya}\}$, dan mereka. Perbedaan antara $\{-\mathrm{i}\}$ dan $\{\mathrm{kae}\}$ adalah jika suku terakhir bentuk dasar berupa vokal (terbuka) digunakan $\{-i\}$, sedangkan jika berakhir dengan konsonan (tertutup) digunkan $\{-\mathrm{kae}\}$.

(2) [ēmē?]'bawa' $\rightarrow$ verba dasar dimarkahi oleh D+/?/

[ēmēēn] 'dibawa oleh' $\rightarrow$ dasar+/ē:/+n (netral, tanpa pelaku)

[èmēēnk] 'dibawa olehku'

$\rightarrow$ dasar+/ē:/+/nk/

[èmēèmp]'dibawa olehmu'

$\rightarrow$ dasar+/ē/:+/mp/

Berdasarkan contoh di atas, nada panjang pada suku akhir /o:/ atau /ê:/ merupakan pemarkah pasif dalam kala lampau, sedangkan bunyi nasal akhir menunjukkan pelaku $(/ \mathrm{nk} /=$ saya atau $\{-\mathrm{ku}\}$, $/ \mathrm{mp} /=\mathrm{kamu}$ atau $\{-\mathrm{mu}\}$ atau tanpa pelaku dengan $/ \mathrm{n} /$.

\section{b. Pembentukan Verba Pasif dengan Prefiks \{teng-\}}

Verba pasif dapat dibentuk dengan prefik \{teng-\}. Bentuk dasar yang diawali dengan fonem $/ \mathrm{k} /$, jika diturunkan menjadi bentuk verba pasif dengan prefiks \{teng-\}, fonem $/ \mathrm{k} /$ luluh atau terjadi nasalisasi $/ \mathrm{y} /$, seperti [kapuut] 'tertutup' $\rightarrow$ [tejaput] 'ditutupi', [kaluuk] 'lauk-pauk' $\rightarrow$ [tenaluk] 'dijadikan lauk', dan [kumaan] 'makan' $\rightarrow$ [tejuman] 'dimakan'.

Berdasarkan contoh di atas, prefiks \{teng-\}berfungsi sebagai pembentuk makna verba pasif. Bentuk dasar yang diawali dengan fonem $/ \mathrm{k} /$ tidak luluh ketika diimbuhi prefiks $\{$ teng- $\}$ dalam penurunan kata yang menyatakan perbuatan jamak, seperti [kelisuuk] 'kejar' $\rightarrow$ [tejkelisuk] 'berkejar-kejaran'.

\section{c. Pembentukan Verba Pasif dengan Prefiks \{teN-\}}

Bentuk dasar yang diawali dengan fonem /a/, jika diturunkan menjadi bentuk verba pasif, diimbuhi $\{$ tem- $\}$ di awal bentuk dasar itu, yaitu dengan cara memendekkan bunyi vokal pada suku akhir bentuk dasarnya, seperti [ajaar] 'bayaran' $\rightarrow$ [temajar] 'dibayar', [apaar] 'titian' $\rightarrow$ [temapar] 'dipasangi titian', dan [atoonk] 'palu' $\rightarrow$ [tematonk] 'dipalu'.

Pembentukan kata dalam BDT dapat dilakukan dengan menggunakan prefiks $\{$ teN- $\}$ yang meluluhkan fonem /p/ pada suku awal bentuk kata dasarnya, seperti pada penurunan kata-kata verba pasif berikut.
1) [pentaai]'bertanya' $\rightarrow$ [tementai] 'ditanyai'.
2) [perasu:q]'menyusul' $\rightarrow$ [temerasuq] 'disusul'.
3) [peresa:q] 'memeriksa' $\rightarrow$ [temeresaq] 'diperiksa'.
4) [peririq]'membaringkan' $\rightarrow$ [temeririq] 'dibaringkan'.
5) [pinaq] 'tepat', 'menepatkan (arah)' $\rightarrow$ [teminaq] 'ditepatkan'.



6) [pinaq] 'pindah' $\rightarrow$ [teminaq 'dipindahkan' $\rightarrow \quad$ [tepinaq] 'terpindahkan'.

Berdasarkan penurunan kata di atas, prefiks $\{$ teN- $\}$ memiliki alomorf $\{$ te- $\}$ dan $\{$ tem- $\}$. Prefiks $\{$ teN- $\}$ berfungsi untuk mengubah verba aktif menjadi bentuk pasif.

7) [pija] 'ikan asin peda' (kata dasar (nomina) $\rightarrow$ [mija] 'membuat peda' (kata turunan (verba aktif)) $\rightarrow$ [temija] 'dijadikan peda'(kata turunan (verba pasif)).

Pada contoh (7) terjadi proses penurunan kata dari nomina pija menjadi verba aktif mija dengan nasalisasi. Kemudian dari verba aktif mija diturukan menjadi temija melalui proses $\{$ teN- $\}$ berubah menjadi $\{$ te- $\}$ karena verba aktifnya diawali fonem nasal $/ \mathrm{m} /$.

8) [pelau] 'mencari' $\rightarrow$ [temelau] 'dicari' $\rightarrow$ [tempelau] 'saling mencari'.

Penurunan kata dengan prefiks $\{$ teN- $\}$ yang beralomorf $\{$ te- $\}$ dan $\{$ tem- $\}$ harus dibedakan antara temelau 'dicari' dan tempelau 'saling mencari'. Fonem awal pada bentuk dasar tidak luluh sehingga peingimbuhan $\{$ tem- $\}$ menyatakan makna resiprokal dengan pengimbuhan $\{$ te- $\}$. Dengan demikian, prefiks $\{$ tem- $\}$ memiliki dua fungsi, yaitu sebagai pemarkah verba pasif dan pemarkah makna resiprokal.

\section{Pembentukan Adverbia}

Adverbia dalam BDT dapat dibentuk dengan dua cara, yaitu dengan pengulangan dwireka dan pemajemukan.

\section{Adverbia dengan Pengulangan Dwireka}

Beberapa contoh adverbia yang dibentuk dengan pengulangan dwireka tertera bawah ini.

1) [demos] 'tersenyum' $\rightarrow$ [demosdencom] 'tersenyum-senyum'.

2) [nina] 'menyanyi' $\rightarrow$ [nina-neraya] 'bernyanyi-nyanyi'.

3) [motok] 'memotong $\rightarrow$ [motok-molan] 'memotong-motong'.

4) [èmpay-empeh] 'terhuyung-huyung karena beban yang berat'.
5) [gerepamp-gerpoos] 'bergeming, tak bergerak dan tak bersuara sama sekali'.

6) [gėar-gèor] 'arus massa yang bergerombol dan bergerak ke sana ke mari'

7) [gauuk-goank]'melolong-lolong kesakitan' (tt. anjing).

8) [gumat-gemut]'bergerak-gerak di balik kain atau kulit'.

9) [golak-golek]'berbaring-baring sembarangan'.

10) [golon-gonaan]'berguling-guling, bersusah payah'.

Bentuk-bentuk reduplikasi dalam BDT menunjukkan adanya kesamaan dengan reduplikasi di dalam bahasa Indonesia, tetapi dalam jumlah yang terbatas, seperti dengan jenis reduplikasi cengar-cengir, hingar-bingar, riuh-rendah, terang-benderang, hiruk-pikuk, dan kocarkacir. Selain itu, ada juga perbedaannya, yaitu reduplikasi dalam BDT tidak ada yang memiliki afiks, sedangkan di dalam bahasa Indonesia banyak sekali reduplikasi berafiks, seperti berlari-larian, berkejarkejaran, bermain-main, bergoyang-goyang, dan menari-nari.

\section{Pembentukan Adverbia dengan Pemajemukan}

Kriteria kemajemukan sebuah kata adalah pembentukan makna baru dari perpaduan dua leksem yang maknanya itu tidak berasal dari makna unsur-unsur leksem pembentuknya. Contoh bentuk-bentuk majemuk dalam BDT sebagai pembentuk adverbia tertera di bawah ini.

1) [nagooi] 'memanggil' $\rightarrow$ [nagooi nomaak] 'memanggil dengan berteriakteriak'.

2) [aluk] 'duluan' $\rightarrow$ [aluk oncéék] 'sesuatu yang tidak berurutan/ tidak tertib'.

3) [ange] 'memantul' $\rightarrow$ [ange dang akuq] 'semua perbuatan akan ada balasannya'.

4) [asakn] 'napas' $\rightarrow$ [asang sengaat] 'belas kasihan'. 
5) [atap] 'mumpung' $\rightarrow$ [atap ilap] 'sekejap mata'.

6) [nentaaq] 'hanya makan lauk atau daging tanpa nasi' $\rightarrow$ [nentaaq nentus] 'makan nasi tanpa lauk'.

7) [yeleyoot] 'menjenguk' $\rightarrow$ [yeleyoot yeledo]'memperhatikan tingkat kehidupan suatu keluarga'.

8) [yeloloomp] 'mengulum' $\rightarrow$ [neloloomp tuñuk] 'gigit jari'.

9) [yohaak] 'istirahat' $\rightarrow$ [yokor yohaak] 'batuk parah tak henti-henti'.

10) [yusut] 'membuat tali menjadi kusut' $\rightarrow$ [yusut yusaat] 'membuat masalah'.

Contoh-contoh kata majemuk di atas menunjukkan bahwa hanya salah satu unsur leksikal yang memiliki arti, yakni kata yang disebutkan pertama, sedangkan leksikon yang kedua tidak mudah ditelusuri makna dasarnya. Penggabungan dua leksikon seperti itu memang lazim juga dalam kata majemuk bahasa Indonesia walaupun jumlahnya lebih terbatas, seperti tunggang langgang, daya juang, dan lintang pukang. Kata-kata yang berada pada urutan kedua, yakni langgang, juang, dan pukang tidak memiliki arti tersendiri.

\section{Penentuan Kelas Kata Preposisi}

Preposisi atau kata depan dalam BDT dapat diidentifikasi berdasarkan fungsinya secara sintaksis atau dengan model valensi. Ada dua hubungan makna yang dapat diungkapkan oleh preposisi secara valensi, yaitu preposisi pengungkap hubungan makna tempat dan pengungkap makna hubungan arah. Dilihat dari posisinya dalam susunan frasa preposisional, ia berada sebelum nomina. Dilihat dari segi bentuknya ada yang berupa kata tunggal dan kata gabungan. Preposisi tunggal terdiri atas satu kata dasar, sedangkan preposisi gabungan terdiri atas dua kata dasar.

\section{Preposisi Tunggal}

1) Preposisi tunggal pengungkap hubungan makna tempat, yaitu

a. [diq] 'di'.

b. [dihik atau [ditih] 'di sini'. c. [dite] atau [dijoq] 'di situ'.

d. [dito] 'di sana'.

e. [digna] 'di bawah'.

$f$. [dinya] 'di mana'.

2) Preposisi tunggal pengungkap hubungan makna arah.

Preposisi tunggal pengungkap hubungan makna arah contohnya [ja]'ke' seperti dalam mééq kaat ja umaq 'Ibu pergi ke ladang'.

\section{Preposisi Gabungan}

Preposisi gabungan terdiri atas dua kata dasar, seperti [baq mooq] 'di atas', [baq lam] 'di dalam (untuk insani)', [sala lamp] atau [lamp] 'di dalam (untuk non-insani)'. Contoh tersebut menunjukkan bahwa dalam BDT untuk menyatakan makna 'di dalam' dibedakan preposisinya. Subjek insani (manusia) menggunakan baq lam sedangkan preposisi untuk subjek noninsani menggunakan preposisi sala lamp.

\section{Penentuan Kelas Kata Konjungtor}

Konjungtor atau kata penghubung dalam BDT hanya memiliki makna sintaksis seperti tersua di bawah ini.

1) Hubungan perlawanan ditandai dengan konjungtor tapi 'tapi', misalnya dalam aq daraaq tapi léloong 'dia cantik tapi juling'.

Dilihat dari valensinya, kelas kata konjungtor ini dapat bervalensi sebagai perlawanan dengan pola nomina +adjektiva1+ tapi+ ajektiva2. Hubungan makna yang dibangun oleh konjungtor tapi menunjukkan perlawanan makna adjektiva juling dengan makna pernyataan sebelumnya, adjektiva cantik.

2) Konjungtor penghubung makna sebab akibat perbuatan atau keadaan, misalnya sukat 'sampai' seperti dalam kalimat besiiq temerupuk sukat teheniiq 'besi dibakar sampai pijar'.

Dilihat dari valensinya pola hubungannya merupakan sebab akibat perbuatan dalam pola nomina+sebab+ 
sukat+ akibat, yaitu perbuatan dibakar sebagai sebab, sedangkan keadaan pijar sebagai akibat.

\section{PENUTUP}

Berdasarkan uraian pembahasan di atas, BDT memiliki kelas kata nomina, verba, adjektiva, adverbia, preposisi, dan konjungtor. Pembentukan pronomina, adjektiva, verba, dan adverbia dapat dilakukan dengan paradigma afiksasi, reduplikasi, atau pemajemukan.

Kelas kata preposisi dan konjungtor dapat ditentukan pembentukannya dengan valensi kata dalam kalimat. Preposisi BDT menunjukkan hubungan makna tempat dan arah. Dilihat dari bentuknya ada yang berupa preposisi tunggal seperti diq dan ada yang berupa preposisi gabungan, seperti baq mooq, baq lam, dan sala lamp. Preposisi baq lam digunakan untuk nomina bernyawa, sedangkan sala lamp digunakan untuk nomina takbernyawa. Konjungtor BDT terdiri atas konjungtor makna perlawanan dengan tapi 'tapi', konjungtor makna hasil atau akibat sukat 'sampai/hingga', dan konjungtor makna sebab akibat ngaan 'karena'.

Penelitian ini memiliki keterbatasan data. Oleh karena itu, peneliti lain disarankan untuk meneliti BDT lebih dalam, terutama mengenai verba aktif dan pasif, perbedaan pemarkah posesif untuk orang ketiga tunggal, dan pembedaan fungsi preposisi baq lam dan ala lamp.

\section{DAFTAR PUSTAKA}

Alwi, H., Dardjowidjojo, S., Lapoliwa, H., \& Moeliono, A. M. (2003). Tata Bahasa Baku Bahasa Indonesia (Edisi Ketiga). Jakarta: Balai Pustaka.

Hadibrata, H., \& Winarti. (2007). Bahasa Dayak Rentenuukng dan Bahasa Banjar di Kalimantan Timur. Samarinda: Kantor Bahasa Kalimantan
Timur, Pusat Bahasa, Departemen Pendidikan Nasional.

Kridalaksana, H. (1994). Kelas Kata dalam Bahasa Indonesia. Jakarta: PT Gramedia Pustaka Utama.

Sugono, D. (2008). Bahasa dan Peta Bahasa di Indonesia. Jakarta: Pusat Bahasa, Departemen Pendidikan dan Kebudayaan.

Teeuw, A. (1962). Some problems in the study of word-classes in Bahasa Indonesia. Lingua, 11 . http://doi.org/https://doi.org/10.1016/0 024-3841(62)90050-5

Van Ophuijsen, C. . (1983). Tata Bahasa Melayu. Jakarta: Djambatan. 